受賞者総説

\title{
二枚貝キャッチ収縮の制御機構に関する生化学的研究
}

(平成 15 年度日本水産学会賞奖励賞受賞)

\author{
船 原大 輔* \\ 三重大学生物資源学部
}

Studies on the regulatory mechanisms involved in catch contraction of molluscan smooth muscles

\section{DAISUKE FUNABARA*}

Faculty of Bioresources, Mie University, Tsu, Mie 514-8507, Japan

二枚貝閉殼筋やムラサキイガイ前足牽引筋 $(\mathrm{ABRM})$ は，長時間にわたって張力を発生し続けることができ る。 ${ }^{1)} こ の$ 現象は古くから知られ，その様子がまるで止 め金（キャッチ）で留めたようであることから，キャッ チ収縮と名付けられた。この特異な筋収縮現象は, 多く の筋生理学者や筋生化学者の関心を誘い, その詳細を解 明するために数多くの研究がこれまでに行われてきた。 しかしながら未だに全貌の解明には至っていない。特に 制御機構に関しては, 謎が多く残された状態である。そ こで本研究では, キャッチ收縮の制御機構を明らかにす ることを目的とし，制御タンパク質の同定を足がかりに して，その分子メカニズムの解明を試みた。

\section{1. キャッチ収縮研究}

キャッチ筋は典型的な平滑筋である。キャッチ筋は, アセチルコリンの分泌に伴って細胞内カルシウム濃度が 上昇し, カルシウムが直接結合することで活性化したミ オシンとアクチンが滑り運動を起こして収縮を開始し, 張力を発生する。2) その後, 細胞内カルシウム濃度が減 少するとキャッチ状態に入り, 長時間にわたって張力を 発生し続けるが，その間エネルギーはほとんど消費され ない。3) キャッチ状態のミオシンは, カルシウムが遊離 して不活性化していると考えられている。キャッチ状態 はセロトニンの分泌によって解除され, 筋肉は張力を失 う。その際細胞内に $\mathrm{cAMP}$ の蓄積がみられ，それによ って cAMP 依存性タンパク質リン酸化酵素（A キナー ゼ）が活性化すると考えられている。出したがって，キ ヤッチ解除には $\mathrm{A}$ キナーゼによって筋原線維タンパク 質がリン酸化されることが必須であると考えられた。す
なわち $\mathrm{A}$ キナーゼの標的タンパク質がキャッチ収縮の 制御因子であり，その同定がキャッチ収縮制御を解明す るために求められた。しかしながら, 同定は困難を極 め, 代表的なキャッチ筋構成タンパク質であるパラミオ シン, 5) ミオシン重鎖(6) 打よびミオシン軽鎖7)がその候補 として報告されたものの，いずれもin vivoに打ける決 定的な証拠がなく，長い間キャッチ収縮制御タンパク質 は不明のままであった。このことが原因で, キャッチ収 縮の研究は停滞し, 最近までほとんど新しい知見が報告 されない状況であった。

\section{2.キャッチ収縮制御タンパク質の同定}

このような背景の下，キャッチが解除される際に特異 的にリン酸化される成分が ABRM スキンドファイバー を用いた実験で特定された。8)すなわち, 放射能標識し た $\left[\gamma^{-32} \mathrm{P}\right] \mathrm{ATP}$ の存在下で, ABRM のキャッチを解除 させた後，そのホモジネイトをSDS-PAGE およびオー トラジオグラフィーに供したところ， $600 \mathrm{kDa}$ のタンパ ク質に特異的に ${ }^{32} \mathrm{P}$ の取り込久が認められた。そこで, $600 \mathrm{kDa}$ 成分がキャッチ収縮制御タンパク質であると考 え，まずその同定を試みた。600 kDa 成分は分子量か ら，ミニタイチンあるいは twitchin と呼ばれる巨大タ ンパク質の関連タンパク質と予想された。既報のホタテ ガイ・ミニタイチンの精製法に従ってムラサキイガイ ABRM から精製を試みた結果, 単一成分として 600 $\mathrm{kDa}$ 成分が得られた。9 精製標品につき,アミノ酸組 成, 部分アミノ酸配列, および $\mathrm{j}$ 掠A クローニングに よる部分一次構造の解析を行ったところ, 線虫 Caenorhabditis elegans twitchin をはじめとするタイチン

* Tel : 81-59-231-9564. Fax : 81-59-231-9557. Email : funabara@bio.mie-u.ac.jp 
/コネクチンファミリータンパク質と高い相同性を示 し, twitchin と同定された。10) twitchin は, 無脊椎動物 筋肉に広く存在する筋原線維タンパク質で, 特に C. elegans の twitchin 欠損株には, 横紋筋組織に横紋構造が 存在せず，正常に筋収縮ができないことから，筋収縮制 御に何らかの役割を果たしていると考えられていた が, 11) 生体内に抢ける機能が具体的に明らかになったの はこれが初めてであった。

\section{3. ムラサキイガイ ABRM twitchin の性状}

3’および 5'RACE 法を用いた cDNA クローニングに より全一次構造を決定したところ，ムラサキイガイ ABRM twitchin は4736アミノ酸残基から構成される 分子量 53 万の 1 本のポリペプチド鎖であることが分か った。12) モチーフ構造は，イムノグロブリン扰びフィ ブロネクチンタイプ 3 様モチーフの繰り返しと, キ ナーゼドメインから構成されて打り, 線虫 twitchin ${ }^{13)}$ 同じファミリーに属するアメリカザリガニ・プロジェク チン14)とよく似た構造を示した。

twitchin 精製標品につきin vitro リン酸化アッセイを 詳細に行ったところ, twitchin は A キナーゼによって 迅速にリン酸化され, 反応開始後すぐに最大リン酸化量 に達した。15) これは, キャッチ状態の解除が速やかに起 きる事実とよく一致した。リン酸化量は twitchin 1 モル あたり 3 モルと算出され, リン酸化部位が複数存在す ることが示唆された。リン酸化 twitchinのトリプシン 完全消化物からリン酸化ペプチドを単離して $\mathrm{N}$ 末端ア ミノ酸配列分析を行ったところ, 主要と思われる $2 つ$ のリン酸化部位 D1 および D2 が同定された。 は $\mathrm{A}$ キナーゼの典型的な認識配列をもち, twitchin 分 子中， $\mathrm{D} 1$ が $\mathrm{N}$ 末端から 7 と 8 番目，また $\mathrm{D} 2$ が $\mathrm{C}$ 末端 から 3 と 4 番目のイムノグロブリン様モチーフをつな ぐ非常に柔軟な領域に存在することが分かった。 ${ }^{12)} \mathrm{D} 1$ あるいは D2 リン酸化部位を特異的に認識する抗体の存 在下で行ったin vivo 張力測定実験で，D1 および D2の 両方がキャッチ收縮制御に関与している可能性が示唆さ れた。12）しかしながら，リン酸化部位のリン酸化，脱リ ン酸化が twitchin の構造にどのような変化をもたらす のか，また，その変化がキャッチ制御にどのような役割 を果たしているのか，詳細は現在のところ不明である。 今後, さらなる研究が必要である。D1 リン酸化部位周 辺のモチーフ構造は，Cタンパク質のそれとよく似てお り, 機能の類似性が示唆された。 ${ }^{12)} \mathrm{C}$ タンパク質はミオ シンフィラメントを束ねる構造的機能を有すると考えら れているものの, 16) 未だ不明な点が多く, 真の機能につ いては明らかでない。ABRM twitchinの解析を通じて $\mathrm{C}$ タンパク質の機能も明らかにできる可能性がある。 キナーゼドメインは, タイチン/コネクチンファミ
リータンパク質に共通に存在するミオシン軽鎖キナーゼ 触媒部位と高い相同性を有する領域で，本ドメインを有 する twitchin やその関連タンパク質がキナーゼ活性を 有すること，また自己リン酸化することが報告されてい る。17-19) そこで，ムラサキイガイ twitchin のキナーゼ活 性について検討するために，種々の条件下で実験を行っ たところ，ABRM twitchinはリン酸化能をもたないこ とが示された。15)

\section{4. カルポニンによる筋収縮制御の可能性}

キャッチ収縮制御が twitchinのリン酸化を通して行 われていることが明らかになり，スイッチのオン・オフ のように，キャッチ収縮制御を明快に説明できるように なった。ところで, 脊椎動物平滑筋でラッチ機構と呼ば れるキャッチ収縮とよく似た現象が観察されることが知 られている。20) ラッチ機構がキャッチ収縮と同様に twitchin もしくはその関連タンパク質によって制御され ているかどうかは全く不明であるが，現在のところラッ チ機構の制御因子の 1 つとして筋原線維タンパク質の 1 つであるカルポニンが報告されている。21) カルポニンは ニワトリ平滑筋で発見されたアクチン結合タンパク質 で，細いフィラメントに結合することで筋収縮を制御し ていると考えられている。22) ラッチとキャッチが似た現 象を示すということは，似たような制御を受けている可 能性を示唆しており，したがってキャッチ収縮制御に力 ルポニンが関与していることが十分に考えられた。しか しながら，カルポニンはいくつかの無脊椎動物で発現が 確認されているものの, 23,24,25) 二枚貝などの軟体動物で の存在の有無は不明であった。そこで，ムラサキイガイ ABRM 筋原線維を二次元電気泳動で展開したところ, 主要構成タンパク質であるミオシン重鎖，ミオシン軽 鎖，アクチン，パラミオシン，抒よびトロポミオシンの ほかに，約 $45 \mathrm{kDa}$ の未知成分のスポットが確認され た。26)この $45 \mathrm{kDa}$ タンパク質を各種クロマトグラフ ィーを用いて ABRM から単離した。部分アミノ酸配列 分析した結果，既報の他生物種由来のカルポニンと高い 相同性を示し，またウェスタンブロッティングで市販の 抗カルポニン抗体と反応性を示し， $45 \mathrm{kDa}$ タンパク質 はカルポニンと同定された。cDNA クローニングによ る全一次構造解析の結果, ABRM カルポニンは 403 ア ミノ酸残基からなり，分子量は 45 万と推定された。27) モチーフ構造は，他生物種由来カルポニンと同様にカル ポニンホモロジードメインとカルポニンドメインから構 成されていた。ABRM カルポニン存在下でアクトミオ シン $\mathrm{Mg}^{2+}$-ATPase 活性を測定したところ，カルポニ ン濃度依存的に活性が阻害されることが明らかとな り, ${ }^{26)} \mathrm{ABRM}$ カルポニンと脊椎動物カルポニンが同様 の機能を有していることが示唆された。したがって， 
ABRM カルポニンがキャッチ収縮制御に何らかの影響 を及ぼしている可能性が考えられた。カルポニンの機能 解析も, キャッチ収縮の制御機構の全貌を明らかにする 上で重要であると思われる。

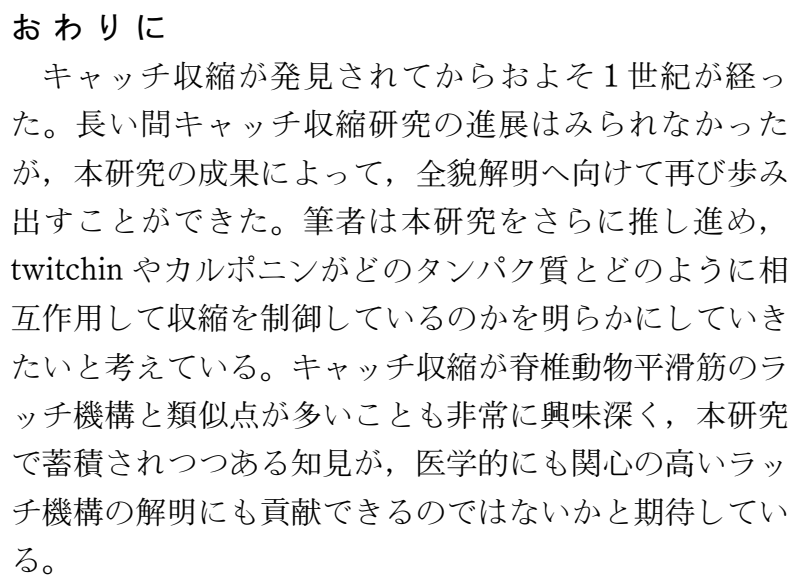

\section{謝辞 \\ 本研究は, 東京大学大学院農学生命科学研究科渡部終 五教授の御指導と御鞭撻の下に遂行されたものであり, ここに深甚なる謝意を表する。また，共同研究者として 貴重な御助言や実験の御指導を頂いたアメリカ合衆国ジ ェファーソン医科大学 Marion J. Siegman 教授抢よび Thomas M. Butler 教授，ならびにアリゾナ大学 David J. Hartshorne 教授に東心より感謝する。さらに，本研 究を御支援していただいた三重大学生物資源学部加納哲 教授に御礼申し上げる。最後に, 実験等で御協力頂いた 東京大学大学院農学生命科学研究科水圈生物工学研究室 および三重大学生物資源学部生体高分子化学研究室の関 係諸氏に心から感謝する。}

\section{文献}

1) Winton FR. The changes in viscosity of an unstriated muscle (Mytilus edulis) during and after stimulation with alternating, interrupted and uninterrupted direct currents. J. Physiol. 1937; 88: 492-511.

2) Szent-Györgyi AG, Chantler PD. Control of contraction by calcium binding to myosin. In: Engel AG, FranziniArmstrong C (eds) Mycology, McGraw Hill, New York, 1994; 506-528.

3) Watabe S, Hartshorne DJ. Paramyosin and the catch mechanism. Comp. Biochem. Physiol. 1990; 96B: 639-646.

4) Achazi RK. 5-HT induced accumulation of $3^{\prime}, 5^{\prime}-\mathrm{AMP}$ and the phosphorylation of paramyosin in the ABRM of Mytilus edulis. Malacologia 1979; 18: 465-468.

5) Watabe $\mathrm{S}$, Tsuchiya T, Hartshorne DJ. Phosphorylation of paramyosin. Comp. Biochem. Physiol. 1989; 94B: 813821.

6) Castellani L, Cohen C. Myosin rod phosphorylation and the catch state of molluscan muscles. Science 1987; 235: 334-337.
7) Sohma H, Yazawa M, Morita F. Phosphorylation of regulatory light chain a (RLC-a) in smooth muscle myosin of scallop, Patinopecten yessoensis. J. Biochem. 1985; 98: 569-572.

8) Siegman MJ, Mooers SU, Li C, Narayan S, Trinkle-Mulcahy L, Watabe S, Hartshorne DJ, Butler TM. Phosphorylation of a high molecular weight $(\sim 600 \mathrm{kDa})$ protein regulates catch in invertebrate smooth muscle. $J$. Muscle Res. Cell Motil. 1997; 18: 655-670.

9) Vibert P, Edelstein SM, Castellani L, Elliott BW Jr. Minititins in striated and smooth molluscan muscles: structure, location and immunological crossreactivity. J. Muscle Res. Cell Motil. 1993; 14: 598-607.

10) Siegman MJ, Funabara D, Kinoshita S, Watabe S, Hartshorne DJ, Butler TM. Phosphorylation of a twitchinrelated protein controls catch and calcium sensitivity of force production in invertebrate smooth muscle. Proc. Natl. Acad. Sci. U.S.A. 1998; 95: 5383-5388.

11) Waterston RH, Thomson JN, Brenner S. Mutants with altered muscle structure of Caenorhabditis elegans. Dev. Biol. 1980; 77: 271-302.

12) Funabara D, Watabe S, Mooers SU, Narayan S, Dudas C, Hartshorne DJ, Siegman MJ, Butler TM. Twitchin from molluscan catch muscle: primary structure and relationship between site-specific phosphorylation and mechanical function. J. Biol. Chem. 2003; 278: 29308-29316.

13) Benian GM, Kiff JE, Neckelmann N, Moerman DG, Waterston RH. Sequence of an unusually large protein implicated in regulation of myosin activity in C. elegans. Nature 1989; 342: 45-50.

14) Oshino T, Shimamura J, Fukuzawa A, Maruyama K, Kimura $\mathrm{S}$. The entire cDNA sequences of projectin isoforms of crayfish claw closer and flexor muscles and their localization. J. Muscle Res. Cell Motil. 2003; 24: 431438.

15) Funabara D, Kinoshita S, Watabe S, Siegman MJ, Butler TM, Hartshorne DJ. Phosphorylation of molluscan twitchin by the cAMP-dependent protein kinase. Biochemistry 2001; 40: 2087-2095.

16) Davis JS. Interaction of $\mathrm{C}$-protein with $\mathrm{pH} 8.0$ synthetic thick filaments prepared from the myosin of vertebrate skeletal muscle. J. Muscle Res. Cell Motil. 1988; 9: 174183.

17) Heierhorst J, Probst WC, Vilim FS, Buku A, Weiss KR. Autophosphorylation of molluscan twitchin and interaction of its kinase domain with calcium/calmodulin. J. Biol. Chem. 1994; 269: 21086-21093.

18) Heierhorst J, Probst WC, Kohanski RA, Buku A, Weiss KR. Phosphorylation of myosin regulatory light chains by the molluscan twitchin kinase. Eur. J. Biochem. 1995; 233: 426-431.

19) Maroto M, Vinos J, Marco R, Cervera M. Autophosphorylating protein kinase activity in titin-like arthropod projectin. J. Mol. Biol. 1992; 224: 287-291.

20) Dillon PF, Aksoy MO, Driska SP, Murphy RA. Myosin phosphorylation and the cross-bridge cycle in arterial smooth muscle. Science 1981; 211: 495-497.

21) Haeberle JR. Calponin decreases the rate of cross-bridge cycling and increases maximum force production by smooth muscle myosin in an in vitro motility assay. J. Biol. Chem. 1994; 269: 12424-12431.

22) Takahashi K, Hiwada K, Kokubu T. Isolation and characterization of a 34,000-dalton calmodulin- and F-actin- 
binding protein from chicken gizzard smooth muscle. Biochem. Biophys. Res. Commun. 1986; 141: 20-26.

23) Irvine M, Huima T, Prince AM, Lustigman S. Identification and characterization of an Onchocerca volvulus cDNA clone encoding a highly immunogenic calponin-like protein. Mol. Biochem. Parasitol. 1994; 65: 135-146.

24) Royuela M, Fraile B, Picazo ML, Paniagua R. Immunocytochemical electron microscopic study and Western blot analysis of caldesmon and calponin in striated muscle of the fruit fly Drosophila melanogaster and in several muscle cell types of the earthworm Eisenia foetida.
Eur. J. Cell Biol. 1997; 72: 90-94.

25) Yang W, Zheng YZ, Jones MK, McManus DP. Molecular characterization of a calponin-like protein from Schistosoma japonicum. Mol. Biochem. Parasitol. 1999; 98: 225-237.

26) Funabara D, Nakaya M, Watabe S. Isolation and characterization of a novel $45-\mathrm{kDa}$ calponin-like protein from anterior byssus retractor muscle of the mussel Mytilus galloprovincialis. Fish. Sci. 2001; 67: 511-517.

27) Funabara D, Nakaya M, Watabe S. Molecular characterization of calponin from molluscan catch muscle. Fish. Sci. 2002; 68: supplement II, 1609-1610. 